\title{
Formation of nighttime sulfuric acid from the ozonolysis of alkenes in Beijing
}

\author{
Yishuo Guo ${ }^{1}$, Chao Yan ${ }^{1,2}$, Chang $\mathrm{Li}^{1}$, Wei Ma ${ }^{1}$, Zemin Feng ${ }^{1}$, Ying Zhou ${ }^{1}$, Zhuohui Lin ${ }^{1}$, Lubna Dada ${ }^{2}$, \\ Dominik Stolzenburg $^{2}$, Rujing Yin ${ }^{3}$, Jenni Kontkanen ${ }^{2}$, Kaspar R. Daellenbach $^{2}$, Juha Kangasluoma ${ }^{1,2}$, Lei Yao ${ }^{2}$, \\ Biwu Chu ${ }^{2}$, Yonghong Wang ${ }^{2}$, Runlong Cai ${ }^{2}$, Federico Bianchi ${ }^{2}$, Yongchun Liu ${ }^{1}$, and Markku Kulmala ${ }^{1,2}$ \\ ${ }^{1}$ Aerosol and Haze Laboratory, Beijing Advanced Innovation Center for Soft Matter Science and Engineering, \\ Beijing University of Chemical Technology, Beijing, China \\ ${ }^{2}$ Institute for Atmospheric and Earth System Research/Physics, Faculty of Science, University of Helsinki, Helsinki, Finland \\ ${ }^{3}$ State Key Joint Laboratory of Environment Simulation and Pollution Control, State Environmental Protection Key \\ Laboratory of Sources and Control of Air Pollution Complex, School of Environment, Tsinghua University, Beijing, China
}

Correspondence: Chao Yan (chao.yan@helsinki.fi)

Received: 2 December 2019 - Discussion started: 30 March 2020

Revised: 7 December 2020 - Accepted: 26 February 2021 - Published: 8 April 2021

\begin{abstract}
Gaseous sulfuric acid (SA) has received a lot of attention for its crucial role in atmospheric new particle formation (NPF). And for this reason, studies until now have mainly focused on daytime SA when most NPF events occur. While daytime $\mathrm{SA}$ production is driven by $\mathrm{SO}_{2}$ oxidation of $\mathrm{OH}$ radicals of photochemical origin, the formation of SA during nighttime and its potential influence on particle formation remains poorly understood. Here we present evidence for significant nighttime SA production in urban Beijing during winter, yielding concentrations between 1.0 and $3.0 \times 10^{6} \mathrm{~cm}^{-3}$. We found a high frequency $(\sim 30 \%)$ of nighttime SA events, which are defined by the appearance of a distinct SA peak observed between 20:00 and 04:00 local time, with the maximum concentration exceeding $1.0 \times 10^{6} \mathrm{~cm}^{-3}$. These events mostly occurred during unpolluted nights with a low vapor condensation sink. Furthermore, we found that under very clean conditions (visibility $>16.0 \mathrm{~km}$ ) with abundant ozone (concentration $>2.0 \times 10^{11} \mathrm{~cm}^{-3}, \sim 7 \mathrm{ppb}$ ), the overall sink of SA was strongly correlated with the products of $\mathrm{O}_{3}$, alkenes and $\mathrm{SO}_{2}$ concentrations, suggesting that the ozonolysis of alkenes played a major role in nighttime SA formation under such conditions. This is in light of previous studies showing that the ozonolysis of alkenes can form $\mathrm{OH}$ radicals and stabilized Criegee intermediates (SCIs), both of which are able to oxidize $\mathrm{SO}_{2}$ and thus lead to SA formation. However, we also need to point out that there exist additional sources of SA
\end{abstract}

under more polluted conditions, which are not investigated in this study. Moreover, there was a strong correlation between SA concentration and the number concentration of sub- $3 \mathrm{~nm}$ particles on both clean and polluted nights. Different from forest environments, where oxidized biogenic vapors are the main driver of nighttime clustering, our study demonstrates that the formation of nighttime cluster mode particles in urban environments is mainly driven by nighttime SA production.

\section{Introduction}

Atmospheric aerosol particles have considerable impact on global climate by directly affecting the radiation balance of the earth and by indirectly acting as cloud condensation nuclei (Stocker et al., 2014). The number concentration of these aerosol particles depends to a large extent on the atmospheric new particle formation (NPF), which includes gas-phase nucleation and subsequent growth of newly formed particles. Studies over the past 20 years have shown that SA is the major gaseous precursor of NPF in most environments inside the continental boundary layer (Lee et al., 2019). SA-driven NPF can proceed as $\mathrm{SA}-\mathrm{H}_{2} \mathrm{O}$ binary nucleation, SA-ammonia $\left(\mathrm{NH}_{3}\right)-\mathrm{H}_{2} \mathrm{O}$ ternary nucleation (Kirkby et al., 2011), SAamine- $\mathrm{H}_{2} \mathrm{O}$ nucleation (Almeida et al., 2013; Kürten et al., 2014), SA-organics nucleation (Riccobono et al., 2014), SA- 
organics- $\mathrm{NH}_{3}$ nucleation (Lehtipalo et al., 2018), and SA$\mathrm{H}_{2} \mathrm{O}-\mathrm{NH}_{3}$-amine nucleation (Myllys et al., 2019; Yu et al., $2012)$. Both the nucleation rate $\left(J_{\text {nuc }}\right)$ and the initial growth rate of newly formed particles tend to have a power-law relationship with the SA concentration: $J_{\text {nuc }}=k \times \mathrm{SA}^{\alpha}$, where the activation nucleation is dominant when $\alpha \approx 1$ (Kulmala et al., 2006), the kinetic nucleation is dominant when $\alpha \approx 2$ (Riipinen et al., 2007; Paasonen et al., 2009; Erupe et al., 2010) and the thermodynamic nucleation becomes more crucial when $\alpha$ is larger than 2.5 (Wang et al., 2011).

Due to the crucial role of SA in NPF, accurate and reliable measurement of SA is of great importance. Up to now, ambient SA concentrations have been reported for many sites (Weber et al., 1997, 1998, 1999; Paasonen et al., 2010; Jokinen et al., 2018; Fiedler et al., 2005; Eisele et al., 2006; Boy et al., 2008; Iida et al., 2008; Wang et al., 2011; Kürten et al., 2016; Yao et al., 2018; Mauldin et al., 2001; Erupe et al., 2010; Yu et al., 2014). These studies indicate that the concentration level of SA in the atmosphere is closely related to human activities. In general, daytime SA concentration is around $10^{5} \mathrm{~cm}^{-3}$ in the pristine Antarctica region (Mauldin et al., 2001); $10^{6} \mathrm{~cm}^{-3}$ in remote continental, remote marine and forest regions (which are less affected by human activities); and $10^{7} \mathrm{~cm}^{-3}$ in urban and rural agricultural lands (which are influenced dominantly by human activities; Birmili et al., 2003; Fiedler et al., 2005; McMurry et al., 2005; Iida et al., 2008; Erupe et al., 2010; Paasonen et al., 2010; Wang et al., 2011; Yao et al., 2018). SA generally shows a distinct diurnal pattern correlating with radiation ( $\mathrm{Lu}$ et al., 2019) with typical concentrations between $10^{6}$ to $10^{7} \mathrm{~cm}^{-3}$ during daytime and $10^{4}$ to $10^{6} \mathrm{~cm}^{-3}$ during nighttime. The seasonal variation of SA is only reported in very few studies, showing higher concentrations during spring and summer than in winter and autumn (Erupe et al., 2010).

Due to the strong connection between SA and NPF, previous studies mostly focused on understanding the SA formation in the daytime. However, recent observation on the formation of sub- $3 \mathrm{~nm}$ particles have shown that these cluster mode particles also exist with high concentration during the night (Junninen et al., 2008; Lehtipalo et al., 2011; Kulmala et al., 2013; Kecorius et al., 2015; Mazon et al., 2016; $\mathrm{Yu}$ et al., 2014) and sometimes even nighttime particle nucleation events can be clearly distinguished. In boreal forest environments, nighttime cluster formation can be attributed to highly oxygenated organic molecules (HOMs) (Kammer et al., 2018; Rose et al., 2018). However, the sources of SA and its role in the particle formation during nighttime remain largely unresolved, and both are the focus of this work. In this study, we show frequent and noticeable increase in SA during nighttime in urban Beijing. We further investigate the main sources of SA and demonstrate its role in the nocturnal formation of sub- $3 \mathrm{~nm}$ clusters.

\section{Nighttime sulfuric acid formation}

During the daytime, gaseous SA is primarily a photochemical product generated from the oxidation of $\mathrm{SO}_{2}$ by $\mathrm{OH}$ radicals, while at nighttime, SA is highly associated with nonphotochemical oxidants, most likely the non-photochemical $\mathrm{OH}$ radicals and stabilized Criegee intermediates (SCIs) (Mauldin et al., 2012; Taipale et al., 2014). And that nonphotochemical SA formation pathway has been investigated in the boreal forest environment (Dada et al., 2020). The nonphotochemical oxidation pathway mainly includes the following reactions. First there is the production of (stabilized) Criegee intermediates (CIs) by the ozonolysis of alkenes,

Alkene $+\mathrm{O}_{3} \stackrel{k_{1}}{\longrightarrow} \varphi \mathrm{SCI}+(1-\varphi) \mathrm{CI}+\mathrm{RCHO}$,

then the direct oxidation of $\mathrm{SO}_{2}$ by long-lived SCIs,

$\mathrm{SCI}+\mathrm{SO}_{2} \stackrel{k_{2}}{\longrightarrow} \mathrm{SO}_{3}+\mathrm{RCHO}$,

or the alternative oxidation of $\mathrm{SO}_{2}$ by $\mathrm{OH}$ radicals formed from decomposition of chemically activated CIs:

$$
\begin{aligned}
& \mathrm{CI} \stackrel{k_{3}}{\longrightarrow} \mathrm{OH}+\mathrm{R}_{1} \mathrm{COR}_{2}, \\
& \mathrm{SO}_{2}+\mathrm{OH} \stackrel{k_{4}}{\longrightarrow} \mathrm{HSO}_{3}, \\
& \mathrm{HSO}_{3}+\mathrm{O}_{2} \stackrel{k_{5}}{\longrightarrow} \mathrm{SO}_{3}+\mathrm{HO}_{2}, \\
& \mathrm{SO}_{3}+2 \mathrm{H}_{2} \mathrm{O} \stackrel{k_{6}}{\longrightarrow} \mathrm{H}_{2} \mathrm{SO}_{4}+\mathrm{H}_{2},
\end{aligned}
$$

where $k_{i}$ is the rate constant of each reaction, and $\varphi$ is the yield of SCIs in the ozonolysis of alkenes. The lifetime of $\mathrm{SO}_{3}$ due to its fast reaction with $\mathrm{H}_{2} \mathrm{O}$ to form SA is approximately $2 \times 10^{-4} \mathrm{~s}$ (see detailed calculation in Supplement Sect. S1), which indicates that this reaction is so fast that almost all $\mathrm{SO}_{3}$ will be instantaneously converted to $\mathrm{SA}$. In this case, the oxidation of $\mathrm{SO}_{2}$ is the rate-limiting step in the formation of SA. Currently, only limited types of SCIs have been studied: isoprene-derived SCIs (Neeb et al., 1997; Zhang et al., 2002; Atkinson et al., 2006; Newland et al., 2015b); monoterpene-derived SCIs (Hatakeyama et al., 1984; Rickard et al., 1999; Zhang and Zhang, 2005; Mauldin et al., 2012; Sipilä et al., 2014; Vereecken et al., 2017); and the simplest SCIs including $\mathrm{CH}_{2} \mathrm{COO}, \mathrm{CH}_{3} \mathrm{CHOO}$ and $\left(\mathrm{CH}_{3}\right)_{2} \mathrm{COO}$ (Hatakeyama et al., 1984; Hasson et al., 2001; Welz et al., 2012; Taatjes et al., 2013; Welz et al., 2014; Newland et al., 2015a; Vereecken et al., 2017). Based on the aforementioned studies, the yield $\varphi$ of SCIs can vary from 0.1 to 0.65 and the rate constants for different reactions span several orders of magnitude, for $k_{1}$ from $1.6 \times 10^{-18}$ to $2.5 \times 10^{-16} \mathrm{~cm}^{3} \mathrm{~s}^{-1}$ and for $k_{2}$ from $1.4 \times 10^{-13}$ to $2.2 \times$ $10^{-10} \mathrm{~cm}^{3} \mathrm{~s}^{-1}$. The yield of $\mathrm{OH}$ radicals from ozonolysis of different type of alkenes also covers a wide range with values of $0.68-0.91,0.24-0.35,0.25-0.44,0.32-0.40$ and $0.33-1.00$ for $\alpha$-pinene, $\beta$-pinene, isoprene, propene and other $\mathrm{C} 4-\mathrm{C} 6$ 
alkenes respectively (Atkinson et al., 1992; Aschmann, 1993; Chew and Atkinson, 1996; Rickard et al., 1999; Siese et al., 2001; Witter et al., 2002; Berndt et al., 2003; Aschmann et al., 2003; Nguyen et al., 2009; Malkin et al., 2010). Moreover, the bimolecular reaction and decomposition reactivity of SCIs is highly structure-dependent. SCIs with more complicated substituent groups tend to react with $\mathrm{H}_{2} \mathrm{O}$ more slowly (Huang et al., 2015), decompose faster (Fenske et al., 2000; Hasson et al., 2001) and are more likely to react with $\mathrm{SO}_{2}$. There were also studies showing that the reactions between SCIs and $\mathrm{SO}_{2}$ were pressure- and temperaturedependent and were commonly affected by the presence of water and other constituents (Kotzias et al., 1990; Sipilä et al., 2014).

\section{Ambient observations}

The continuous and comprehensive measurements were conducted at the west campus of Beijing University of Chemical Technology $\left(39.95^{\circ} \mathrm{N}, 116.31^{\circ} \mathrm{E}\right)$. Here we investigate the time period from 18 January to 15 March 2019. The measuring instruments are located on the fifth floor, which is about $15 \mathrm{~m}$ above the ground level. This station is a typical urban site, which is around $130 \mathrm{~m}$ from the nearest Zizhuyuan Road, $550 \mathrm{~m}$ from the West Third Ring Road, and surrounded by commercial properties and residential dwellings.

\subsection{Measurement of sulfuric acid with CI-APi-TOF}

Sulfuric acid was measured by a long time-of-flight chemical ionization mass specter (LTOF-CIMS, Aerodyne Research, Inc.) equipped with a nitrate chemical ionization source. The basic working principle of this instrument can be found elsewhere (Jokinen et al., 2012). In our measurement, we draw air through a stainless-steel tube with a length of $1.6 \mathrm{~m}$ and a diameter of $3 / 4 \mathrm{in}$. with a flow rate of $7.2 \mathrm{~L} \mathrm{~min}^{-1}$. In addition, we have implemented a flush plate (Karsa Inc.) to effectively remove water molecules entering the instrument, which is necessary to maintain a continuous measurement.

The quantification of sulfuric acid is derived from the ratio of bisulfate ions (with counting rates unit in ions $\mathrm{s}^{-1}$ ) relative to primary ions as follows:

$$
\left[\mathrm{H}_{2} \mathrm{SO}_{4}\right]=\frac{\mathrm{HSO}_{4}^{-}+\mathrm{H}_{2} \mathrm{SO}_{4} \mathrm{NO}_{3}^{-}}{\mathrm{NO}_{3}^{-}+\mathrm{HNO}_{3} \mathrm{NO}_{3}^{-}+\left(\mathrm{HNO}_{3}\right)_{2} \mathrm{NO}_{3}^{-}} \times C .
$$

The calibration coefficient, $C$, is determined from direct calibration by injecting gaseous sulfuric acid of known amounts into the instrument (Kürten et al., 2012). The diffusional wall loss of the 1.6 sampling line is 0.2129 , and after taking this into account, a value of $6.07 \times 10^{9} \mathrm{~cm}^{-3}$ is obtained as the final calibration coefficient.

\subsection{Measurement of alkenes with SPI-MS}

Six alkenes are analyzed in this study, i.e., propylene, butylene, butadiene, isoprene, pentene and hexene, which were detected by a single photon ionization time-of-flight mass spectrometer (SPI-MS 3000, Guangzhou Hexin Instrument Co., Ltd., China) (Gao et al., 2013). It should be mentioned that this instrument cannot distinguish isomers, and therefore the pentene and haxene could also be cyclopentane and cyclohexane, respectively. A polydimethylsiloxane (PDMS) membrane sampling system is used. As the PDMS membrane has better selective adsorption to volatile organic compounds (VOCs), VOC molecules can be concentrated after diffusing and desorbing from the membrane under vacuum sampling conditions. In this way, the detection limit of VOCs can be improved. Then the gas molecules are guided to an ionization chamber through a $2 \mathrm{~mm}$ diameter stainless steel capillary, where VOC molecules with an ionization energy smaller than $10.8 \mathrm{eV}$ are ionized by the vacuum ultraviolet (VUV) light. For the detection of positive ions, two microchannel plates (MCPs; Hamamatsu, Japan) assembled with a chevron-type configuration are employed. An analogto-digital-converter (ADC) was used to measure and record the output current signal from the MCPs.

Alkene concentrations are quantified by performing a direct calibration. The PAMS (Photochemical Assessment Monitoring Stations) and TO-15 environmental gases (including 57 and 65 types of VOCs separately; Linde Gas North America LLC, USA) are used as two standard gases with ultra-high-purity nitrogen as the carrier gas. Gases with different concentrations of VOCs are produced by mixing a constant carrier gas with standard gas of varying flow rates. The calibration coefficient is further calculated from the ratio between the actual concentration and the ion intensity.

\subsection{Other ancillary measurements}

The number concentration of clusters with the size range of $1.30-2.45 \mathrm{~nm}$ was measured with a particle sizer magnifier (PSM) (Vanhanen et al., 2011), and the integrated number concentration of particles from PSM is referred to as $N_{\text {sub-3 }} \mathrm{nm}$. The number size distributions of aerosol particles from 6 to $840 \mathrm{~nm}$ and from 0.52 to $19.81 \mu \mathrm{m}$ are measured by the differential mobility particle sizer (DMPS) (Aalto et al., 2001) and the aerodynamic particle sizer (APS) (Armendariz and Leith, 2002) respectively. Meteorological parameters are measured at a weather station (AWS310, Vaisala Inc.) located on the rooftop of the building. These parameters include the ambient temperature, relative humidity $(\mathrm{RH})$, pressure, visibility, UVB radiation, and horizontal wind speed and direction. Trace gas concentrations of carbon monoxide $(\mathrm{CO})$, sulfur dioxide $\left(\mathrm{SO}_{2}\right)$ nitrogen oxides $\left(\mathrm{NO}_{x}\right)$ and ozone $\left(\mathrm{O}_{3}\right)$ are monitored using four Thermo Environmental Instruments (models 48i, 43i-TLE, 42i, 49i, respectively). Calibration of these instruments is performed monthly us- 
ing the standard gases of known concentrations. The mass concentration of $\mathrm{PM}_{2.5}$ is directly measured with a tapered element oscillating microbalance dichotomous ambient particulate monitor (TEOM 1405-DF, Thermo Fisher Scientific Inc, USA) with a total flow rate of $16.67 \mathrm{~L} \mathrm{~min}^{-1}$. In addition, the loss rate of gas-phase sulfuric acid described by the condensation sink (CS) is calculated based on the size distribution data from DMPS and APS (Kulmala et al., 2001).

\section{Results and discussions}

\subsection{Definition of nighttime sulfuric acid event}

An overview of our measurements during 18 January to 15 March 2019 is shown in Fig. 1. As our measurement period overlaps with the heating period in Beijing (from 15 November 2018 to 15 March 2019), the $\mathrm{SO}_{2}$ level during the measurement period was higher than that of other periods in one year from 16 March to 31 May 2019 (Fig. S1).

In this work, the nighttime window is defined between 20:00 and 04:00 (the next day) to exclude any possible influence of photochemistry. Figure 2 shows the diurnal variation of SA concentration on one typical SA event night (14 March 2019) and one typical SA non-event night (3 February 2019). In general, nighttime SA concentration varies between $3.0 \times 10^{5}$ and $3.0 \times 10^{6} \mathrm{~cm}^{-3}$ during our measurement period. The nighttime event in Fig. 2 shows a distinct SA peak at around 22:00 with a maximum SA concentration of around $3.0 \times 10^{6} \mathrm{~cm}^{-3}$, which is almost half of the daily maximum value, while in the non-event case, SA continues to decrease throughout the evening, reaching a minimal value of $3.0 \times 10^{5} \mathrm{~cm}^{-3}$. A nighttime SA event is defined when both of the following two criteria are met: (a) there is a distinct peak during the nighttime hours, (b) the SA concentration exceeds $1.0 \times 10^{6} \mathrm{~cm}^{-3}$. The nights without distinct peaks are classified as SA non-event nights, and if a peak is identified but it does not meet criterion (b), the night is classified as an undefined night. Among all 56 nights studied, there are in total $18 \mathrm{SA}$ event nights, 16 non-event nights and 22 undefined nights (listed in Supplement Table S1). Thus, the overall frequency of nighttime SA events during our observation period is $32 \%$, which means that nearly a third of nights during our observation period had distinct nighttime sulfuric acid peaks.

\subsection{Features of nighttime sulfuric acid event}

We further analyzed the features of nighttime SA event nights based on the abovementioned 18 event nights and 16 non-event nights (Fig. 3). On SA event nights, the mass concentration of $\mathrm{PM}_{2.5}$ and the mixing ratio of $\mathrm{NO}_{x}, \mathrm{CS}$ and $\mathrm{RH}$ were clearly lower, and visibility was clearly higher than that on non-event nights. This suggests that nighttime SA events tend to occur under clean conditions. In addition, higher concentrations of $\mathrm{O}_{3}$ were associated with $\mathrm{SA}$ event nights, whereas the concentration of $\mathrm{SO}_{2}$ did not vary too much between SA event and non-event nights. And this indicates that at most of the time, the concentration of $\mathrm{SO}_{2}$ is not the dominant factor that explains the variation of nighttime SA.

We further investigated the determining factor for the occurrence of SA events by looking into different variables during the SA event nights. CS measurements were available for 13 event nights, during which $15 \mathrm{SA}$ peaks were observed. In general, we found that eight events $(53 \%)$ were mainly associated with the decrease in CS. This is demonstrated in Fig. 4, where the nighttime events as well as the simultaneous decrease in CS are highlighted with green dots. Four other cases $(27 \%)$ were mostly due to the increase in $\mathrm{SO}_{2}$ concentration (Fig. S2), and the remaining three cases were likely synergistically caused by $\mathrm{SO}_{2}, \mathrm{O}_{3}$, alkenes, $\mathrm{CS}$ and other parameters. More details are provided in Table S2.

\subsection{Source and sink balance for nighttime sulfuric acid: importance of alkene ozonolysis}

As discussed above, nighttime SA events mainly occurred under clean conditions with a low CS value. Therefore, we classified all the nighttime data into three groups according to the air pollution level, which is assessed by visibility. The division standards for pollution level is explained in detail in Sect. S3. The clean (named Clean-1), mildly polluted and heavily polluted conditions are defined by visibility values which are larger than $12.0 \mathrm{~km}$, in the range of $4.0-12.0 \mathrm{~km}$ and smaller than $4.0 \mathrm{~km}$, respectively. Accordingly, data points under each condition took up $48 \%, 25 \%$ and $27 \%$ of all data points.

After classifying the data set into groups based on the pollution level, the balance between SA source and sink for each group was investigated separately. The ozonolysis of alkenes under dark conditions is capable of generating SCIs as well as $\mathrm{OH}$ radicals, both of which are able to oxidize $\mathrm{SO}_{2}$ to form gaseous SA. However, the yields of both SCIs and recycled $\mathrm{OH}$ radicals remain largely unquantified. Therefore, we do not attempt to distinguish the contribution of SCIs and $\mathrm{OH}$ radicals on SA formation in this study but rather treat them as a "bulk oxidant" and use an empirical parameter $k_{\text {app }}$ to account for both oxidation pathways. Accordingly, the source term (production rate) of SA can be expressed as $k_{\text {app }}$ [Alkene][ $\left.\mathrm{O}_{3}\right]\left[\mathrm{SO}_{2}\right]$, where $k_{\text {app }}$ is an overall empirical parameter that takes into account the yields of $\mathrm{OH}$ radicals and SCIs as well as the rate constants of their reactions with $\mathrm{SO}_{2}$. The sink term (loss rate) consists of two parts: the condensation of SA onto particles ([SA]CS) and the collision of SA monomers with each other to form SA dimers $\left(\beta[\mathrm{SA}]^{2}\right)$. In reality, the SA monomer also collides with SA dimers and larger clusters, but due to the low concentration of SA clusters, those collisions are negligible compared to other losses. In a polluted environment where strong stabilizers of SA exist, the formation rate of stable SA dimers is close to the collision limit (Yao et al., 2018). Therefore, $\beta$ can 


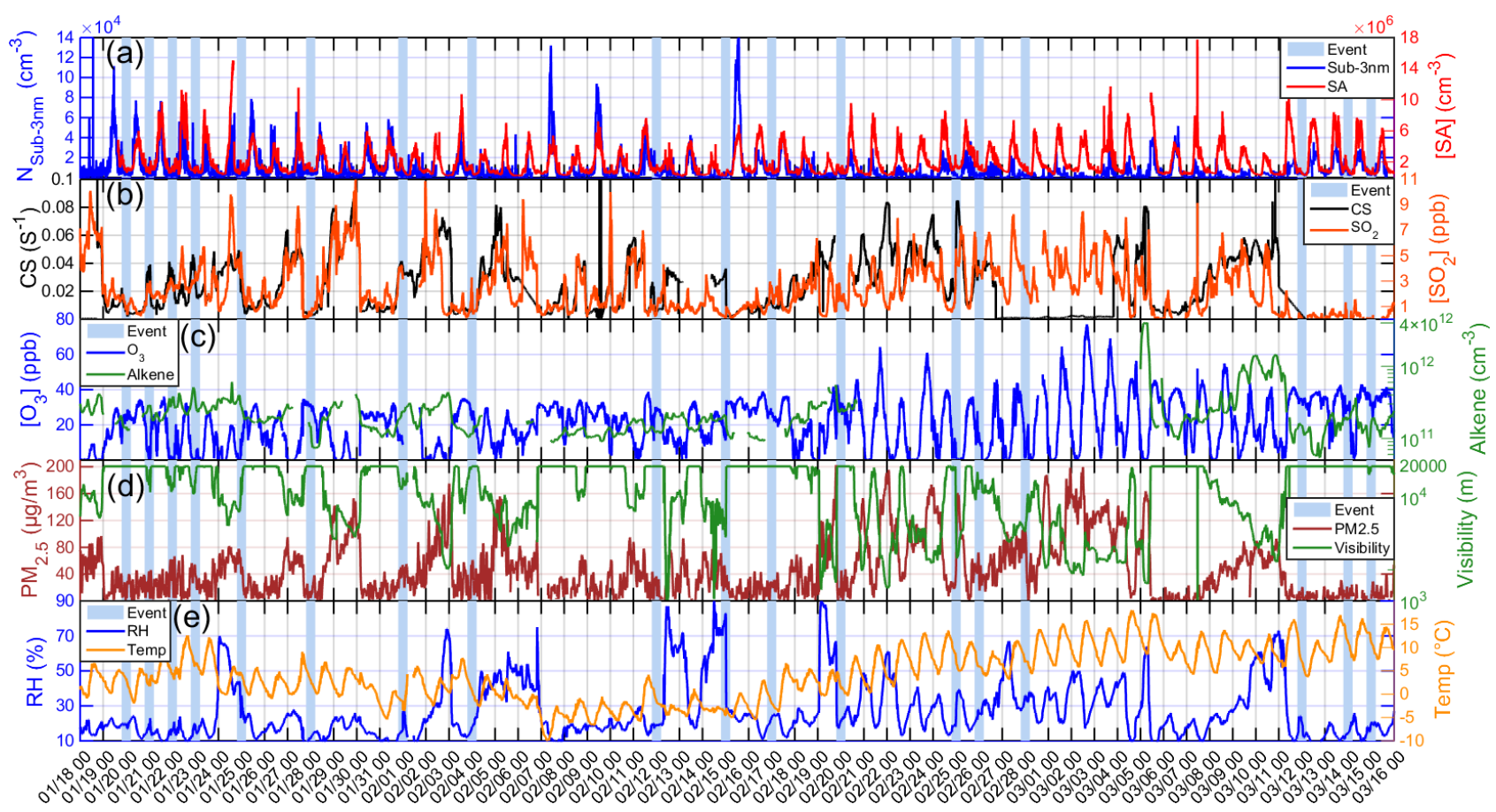

Figure 1. Overview of different parameters measured from 18 January to 15 March 2019 for (a) SA concentration and particle number concentration of sub-3 nm particles $\left(N_{\text {sub- } 3 \mathrm{~nm}}\right.$, measured by PSM), (b) $\mathrm{CS}$ and $\mathrm{SO}_{2}$ concentration, (c) concentration of $\mathrm{O}_{3}$ and alkenes, (d) $\mathrm{PM}_{2.5}$ and visibility, and (e) relative humidity $(\mathrm{RH})$ and temperature. The light blue bars represent nights with nighttime SA events.

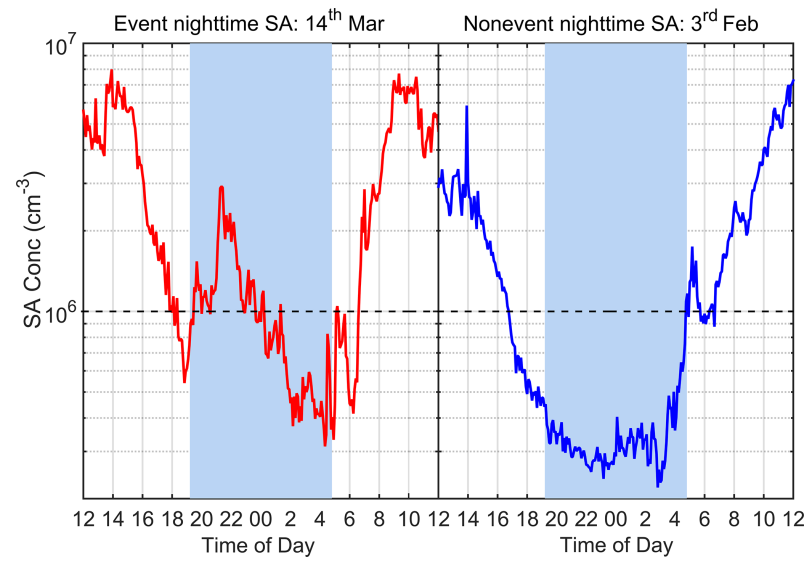

Figure 2. Daily variation of SA concentration on a typical night with a nighttime SA event (red line, 14 March 2019) and on a non-event night (blue line, 3 February 2019). The shaded blue area shows the period that is considered as nighttime in this study.

be taken as the hard-sphere collision rate, which is calculated to be $3.46 \times 10^{-10} \mathrm{~cm}^{3} \mathrm{~s}^{-1}$ (Seinfeld and Pandis, 2016). Under pseudo-steady-state (PSS) assumptions (see Sect. S2 for a detailed discussion of PSS assumptions), the source-sink balance of SA can be expressed as follows:

$k_{\text {app }}[$ Alkene $]\left[\mathrm{O}_{3}\right]\left[\mathrm{SO}_{2}\right]=[\mathrm{SA}] \mathrm{CS}+\beta[\mathrm{SA}]^{2}$.
Figure 5 shows the nighttime correlation between SA source terms and sink terms under different pollution levels, with the data binned by SA sources. If the source and the sink terms correlate, then the slope represents the overall apparent rate constant $\left(k_{\text {app }}\right)$ concerning the reaction between oxidants $\left(\mathrm{OH}\right.$ radicals and SCIs) from ozonolysis of alkenes and $\mathrm{SO}_{2}$ for this specific pollution level.

Under Clean-1 conditions (Fig. 5a), the source term and sink term have a good linear correlation $\left(R^{2}=0.97\right)$ in the source range of $1.0 \times 10^{33}-4.5 \times 10^{33}\left(\mathrm{~cm}^{-3}\right)^{3}$, while the balance is broken up outside of this range. These uncorrelated data points outside of this range appear when the visibility was smaller than $16.0 \mathrm{~km}$ (Fig. S4a) along with higher concentrations of $\mathrm{NO}_{x}$ and $\mathrm{NO}\left(\left[\mathrm{NO}_{x}\right]>\sim 40 \mathrm{ppb}\right.$ in Fig. S4b and ([NO] $>\sim 3$ ppb in Fig. S4c). High $\mathrm{NO}_{x}$ levels always relate to pollution, and $\mathrm{NO}$ will consume $\mathrm{O}_{3}$, leading to much lower $\mathrm{O}_{3}$ concentration (marked by blue empty circles in Fig. S4a). Thus, we redefined the criterion for clean conditions (Clean-2) so that visibility needs to be larger than $16.0 \mathrm{~km}$ and $\mathrm{O}_{3}$ concentration higher than $2.0 \times 10^{11} \mathrm{~cm}^{-3}$ $(\sim 7 \mathrm{ppb})$. These conditions account for $38 \%$ of all data. Figure $5 \mathrm{~b}$ shows the good correlation between the $\left[\mathrm{SO}_{2}\right]\left[\mathrm{O}_{3}\right]$ [Alkene] source term and [SA]CS $+\beta[\mathrm{SA}]^{2}$ sink term $\left(R^{2}=\right.$ $0.97)$ under the redefined clean conditions over the entire source range. This suggests that the ozonolysis of alkenes indeed has a dominant contribution to the formation of SA during nighttime under clean conditions. Generally, the sink 

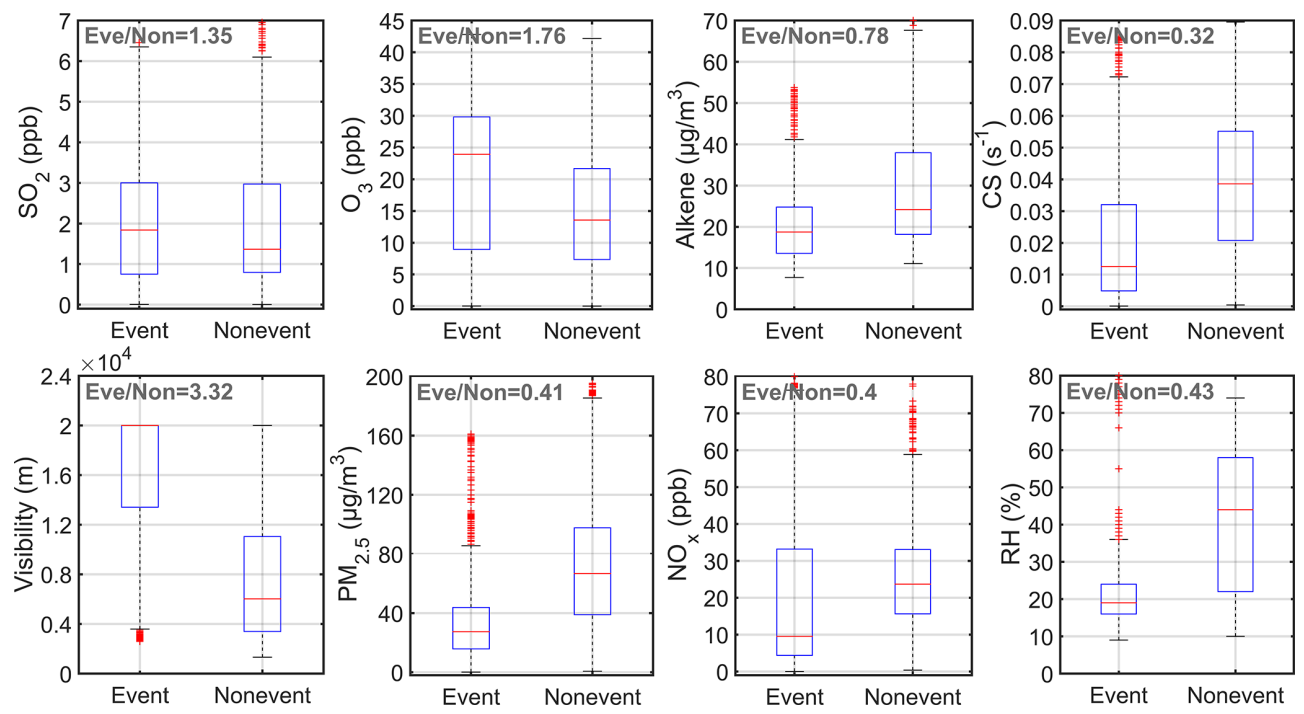

Figure 3. Boxplots for the concentrations of $\mathrm{SO}_{2}, \mathrm{O}_{3}$, alkenes, $\mathrm{CS}$, visibility, $\mathrm{PM}_{2.5}, \mathrm{NO}_{x}$ concentration and $\mathrm{RH}$ during $\mathrm{SA}$ event and nonevent nights. In each plot, the red line is the median value, the bottom and the top blue lines are the 25 and 75 percentiles, and the whisker range covers the $\pm 2.7 \sigma$ of the data. Outliers are the ones out of the $\pm 2.7 \sigma$ range of all selected data. The dark gray values on the top-left corners are the ratios between median values of event and non-event days.

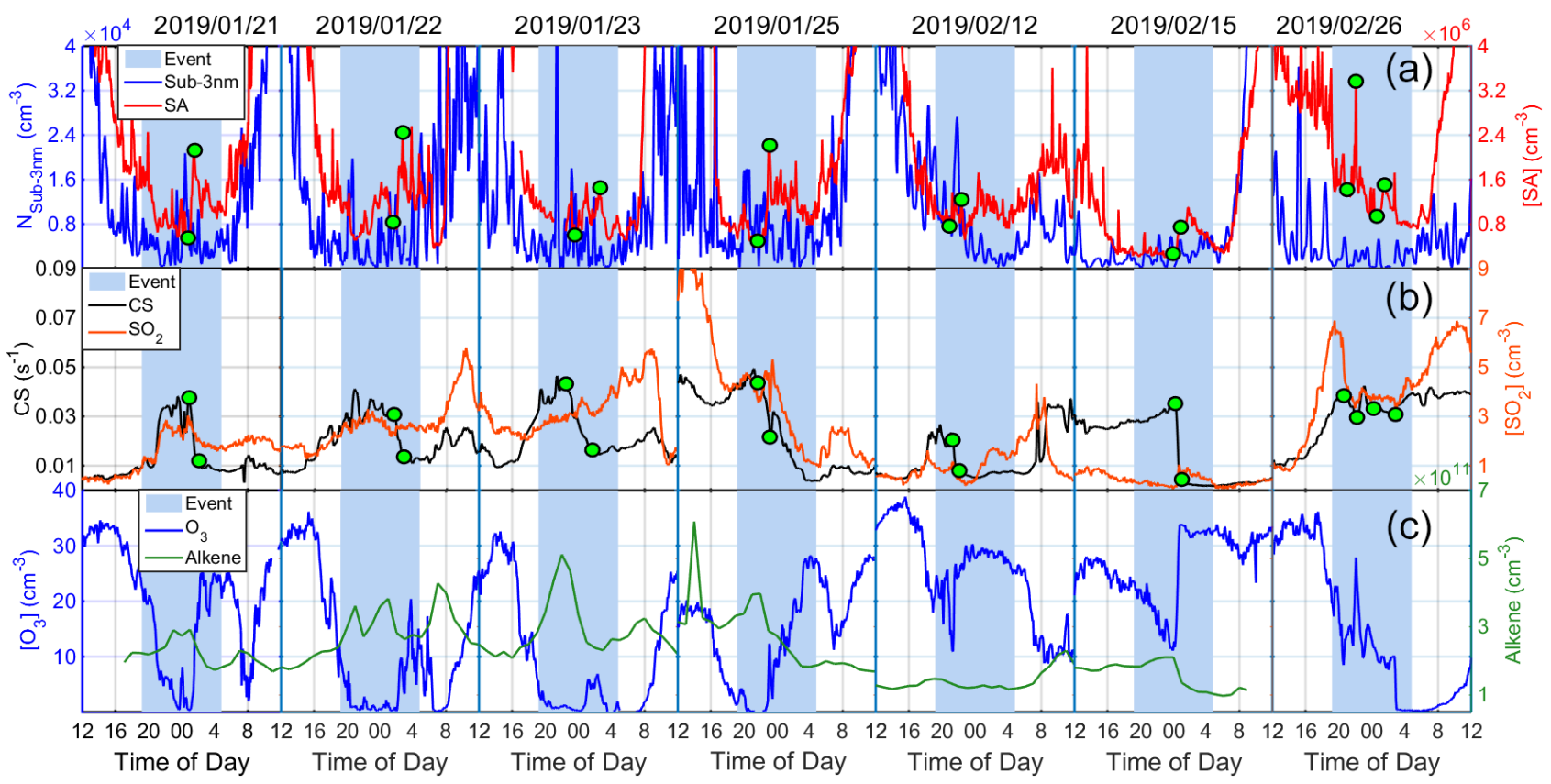

Figure 4. Daily time series of different variables on nighttime SA event days when SA events occurred under CS decrease conditions. Panel (a) shows the $N_{\text {sub- } 3 \mathrm{~nm}}$ and $\mathrm{SA}$ concentration, (b) shows $\mathrm{CS}$ and $\mathrm{SO}_{2}$ concentration, and (c) shows the concentration of $\mathrm{O}_{3}$ and alkenes. Green dots show times when CS started to drop and reached its minimum value.

term of SA condensation onto particles took up $95.5 \%$ for Clean-2 conditions and increased to $99.7 \%$ for heavily polluted conditions. The fitted value, $95 \%$ confidence bounds, uncertainty of $k_{\text {app }}$ and correlation coefficient $R^{2}$ for Clean-1 and Clean- 2 conditions are listed in Table S3.
If we compare the SA source and sink correlation between the Clean-1 (Fig. 5a) and Clean-2 (Fig. 5b) conditions, it is obvious that the slope of the linear region of Clean- 1 condition data points $\left(2.7 \times 10^{-30} \mathrm{~cm}^{6} \mathrm{~s}^{-1}\right)$ matches well with the slope of Clean- 2 condition data points $\left(2.6 \times 10^{-30} \mathrm{~cm}^{6} \mathrm{~s}^{-1}\right)$, which further confirms the reliabil- 


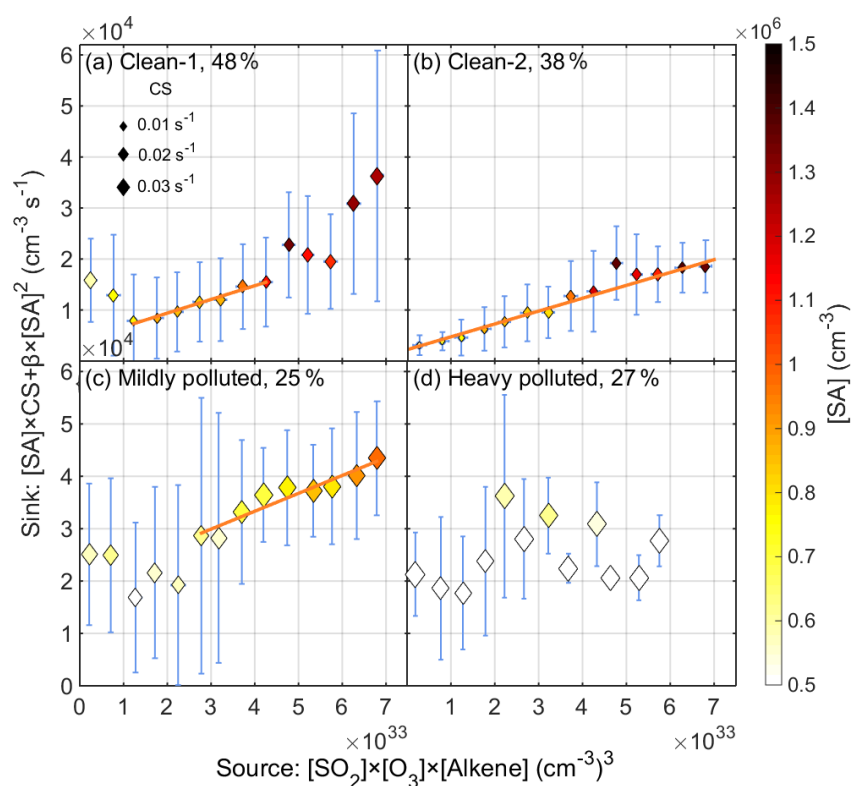

Figure 5. Correlation between the source term $\left(\left[\mathrm{SO}_{2}\right]\left[\mathrm{O}_{3}\right][\right.$ Alkene] $)$ and sink term $\left([\mathrm{SA}] \mathrm{CS}+\beta[\mathrm{SA}]^{2}\right)$ of $\mathrm{SA}$ under PSS assumptions during nighttime (20:00-04:00 next day) from 18 January to 15 March 2019 for (a) Clean-1 conditions, (b) Clean-2 conditions, (c) mildly polluted conditions and (d) heavily polluted conditions. Note that the data points are mean values of corresponding bin ranges instead of the original, high-timeresolution data (Fig. S5). The error bars are the standard deviation of all data points in each bin.

ity of the balance between the $\left[\mathrm{SO}_{2}\right]\left[\mathrm{O}_{3}\right][$ Alkene] source term and $[\mathrm{SA}] \mathrm{CS}+\beta[\mathrm{SA}]^{2}$ sink term under clean conditions. We then took data from another period to further evaluate the reliability of the proposed source and sink balance. For spring period from 20 March to 20 May 2019 (Fig. S7b), there is also a good linear correlation $\left(R^{2}=0.98\right)$ when the source term is smaller than $6.0 \times 10^{33}\left(\mathrm{~cm}^{-3}\right)^{3}$ with $k_{\text {app }}$ of $1.5 \times 10^{-30} \mathrm{~cm}^{6} \mathrm{~s}^{-1}$. Although the fitted $k_{\text {app }}$ values deviate between these two periods, they are in the same order of magnitude. During the spring period, apart from the above-mentioned six alkenes, biogenic emitted monoterpenes, which cannot be measured by our instrument and therefore are not included in the source term, start to have a bigger contribution, which likely leads to the deviation of $k_{\text {app. }}$. As well as this, the yield of SCIs and the rate constant between $\mathrm{SCI}$ and $\mathrm{SO}_{2}$ are to some extent temperaturedependent (Berndt et al., 2014), which may further explain at least part of the difference of $k_{\text {app }}$ between winter and spring observations.

Under mildly polluted conditions (Fig. 5c), the source and sink term also have a good linear correlation when the source value exceeds $2.5 \times 10^{33}\left(\mathrm{~cm}^{-3}\right)^{3}$, while under heavily polluted conditions, the $\left[\mathrm{SO}_{2}\right]\left[\mathrm{O}_{3}\right][$ Alkene] source term and $[\mathrm{SA}] \mathrm{CS}+\beta[\mathrm{SA}]^{2}$ sink term do not show a strong correlation (Fig. 5d). Most likely, this suggests that the source term cannot fully represent the actual SA source for heavily polluted conditions. For instance, there are likely additional sources of SA, such as direct emission from diesel vehicles, oil refineries, SA plants, and any other factories that use coal as heating or power supply (Srivastava et al., 2004; Arnold et al., 2006; Ahn et al., 2011; Roy et al., 2014; Sarnela et al., 2015; Godunov et al., 2017). As well as this, a recent study shows that $\mathrm{SO}_{3}$ generated from the reaction of $\mathrm{SO}_{2}$ on the surface of soot particles potentially leads to the formation of SA during nighttime and early morning (Yao et al., 2020). However, the correlation between the nighttime $\mathrm{SA}$ and $\mathrm{SO}_{3}$ was only found during polluted periods (Fig. S10), suggesting that it might have an important contribution during polluted cases. This may, at least to some extent, explain the extra SA sources under polluted conditions. Another possible cause for the correlation deviation under polluted conditions, and to some extent also mildly polluted conditions, is that the distribution of alkenes may not be constant for measurements classified into the same pollution level, that is, the $k_{\text {app }}$ is not constant. On very clean nights when alkenes sources are considered more local and stable, dramatic changes in alkene distribution are not expected. Moreover, our instrument is only capable of measuring a limited amount of alkene species, and the fitted parameter $k_{\text {app }}$ might be overestimated.

A well-tuned box model is a useful tool to resolve it and verify the role of the ozonolysis of alkenes on the nighttime SA formation. However, such a modeling work is not included in our study, as the lack of a complete VOC data sets and the large uncertainties in yields of SCIs and oxidation rate constants of $\mathrm{SO}_{2}$ by SCIs have posed challenges in ensuring the precision of the box model.

\subsection{Atmospheric implication: contribution of nighttime sulfuric acid to sub-3 $\mathrm{nm}$ particles}

We show that the ozonolysis of alkenes is the major source for the considerable amount of SA that exists at night, at least under unpolluted conditions. As well as this, we found that increasing SA concentration coincided with increasing number concentration of sub-3 $\mathrm{nm}$ particles (Fig. 6a), suggesting that SA had a strong enhancement in the formation of newly formed particles, which is consistent with a previous study (Cai et al., 2017). Different from SA, there was a negative correlation between the concentration of highly oxygenated organic molecules (HOMs) and $N_{\text {sub-3 }} \mathrm{nm}$ for both nighttime and daytime (see Fig. S8), indicating that HOMs were not the main driver for the formation of sub-3 $\mathrm{nm}$ particles. This phenomenon is in contrast with some previous observations in forested areas where oxidation products of biogenic VOCs, especially monoterpene, were the main contributor to the formation of clusters (Eerdekens et al., 2009; Lehtipalo et al., 2011; Kammer et al., 2018; Rose et al., 2018). Both observation (Rose et al., 2018) and laboratory experiments (Lehtipalo et al., 2018) have shown that HOM dimers with extremely low volatility play a key role in the initial forma- 

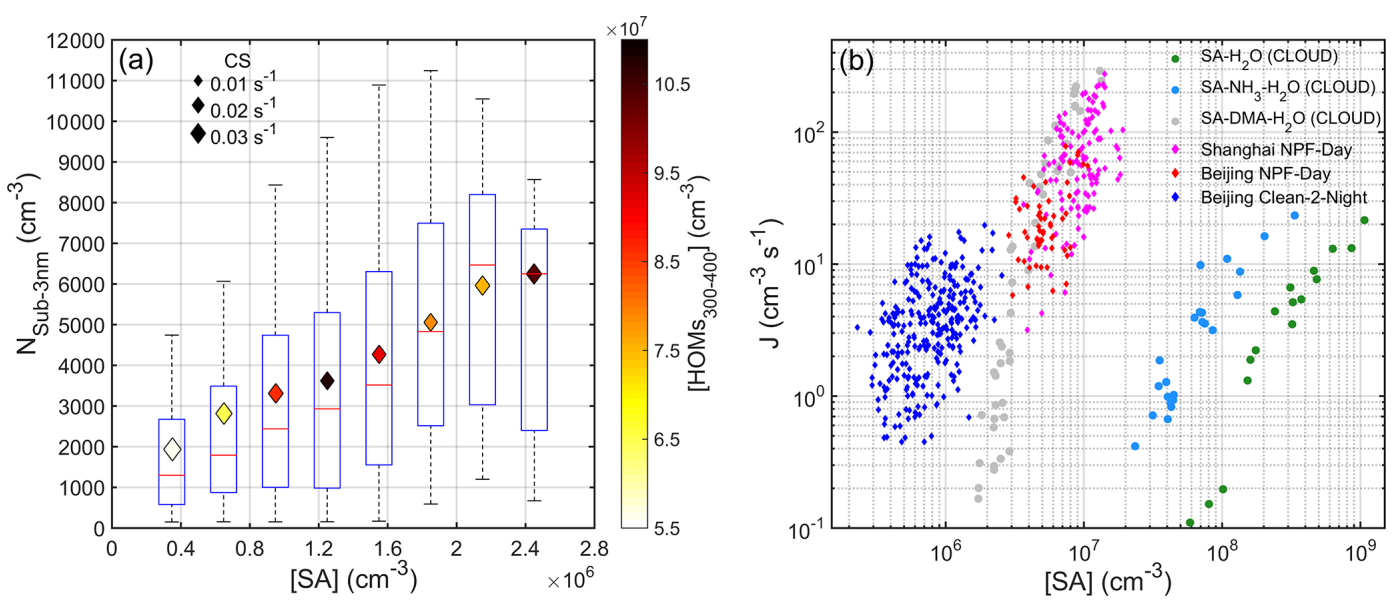

Figure 6. (a) Correlation between $N_{\text {sub- } 3 \mathrm{~nm}}$ and SA concentration during nighttime (20:00-04:00 next day) from 18 January to 15 March 2019. The binned diamonds are colored by number concentration of HOMs $(m / Q=300-400 \mathrm{Th})$, and the size is related to CS. The red line is the median value, the bottom and the top blue lines are the 25 and 75 percentiles, and the whisker ranges cover the $\pm 2.7 \sigma$ of those data in each bin. (b) Comparison of Beijing ambient, Shanghai ambient and CLOUD experimental cluster formation rates against SA concentration. Green, light blue and gray dots denote CLOUD $J_{1.7}$ data for $\mathrm{SA}-\mathrm{H}_{2} \mathrm{O}, \mathrm{SA}-\mathrm{NH}_{3}-\mathrm{H}_{2} \mathrm{O}$ and $\mathrm{SA}-\mathrm{DMA}-\mathrm{H}_{2} \mathrm{O}$ nucleation respectively (Almeida et al., 2013; Kirkby et al., 2011). Magenta diamonds represent Shanghai NPF $J_{1.7}$ data (Yao et al., 2018). Red and blue diamonds are Beijing $J_{1.5}$ data for NPF day (10:00-14:00) and Clean-2 night (20:00-04:00), respectively.

tion of clusters; however, at our site in urban Beijing, a high level of $\mathrm{NO}_{x}$ inhibited the production of HOM dimers and most HOMs are monomers, which have minor importance to the formation of sub- $3 \mathrm{~nm}$ particles. Nighttime sub- $3 \mathrm{~nm}$ particles have also been observed at a suburban site (Kecorius et al., 2015) and areas which are strongly influenced by coastal air masses (Yu et al., 2014; Salimi et al., 2017), but the underlying mechanisms are still unclear. Figure $6 \mathrm{~b}$ shows that the particle nucleation rates $(J)$ in nighttime and the daytime roughly fall on the same line, which also agree well with those from Shanghai observation and the CLOUD chamber SA-DMA (dimethylamine) $\mathrm{H}_{2} \mathrm{O}$ experiment. The similar $J-$ SA relationship between nighttime and the daytime suggests a similar nucleation mechanism to SA-base clustering. Yao et al. (2018) proposed that in urban megacities, high concentrations of DMA together with SA were enough to explain the particle growth to $\sim 3$ nanometers. Therefore, the formation of nighttime as well as daytime sub- $3 \mathrm{~nm}$ particles at our site was more likely the product of SA-DMA- $\mathrm{H}_{2} \mathrm{O}$ nucleation. As well as this, Almeida et al. (2013) suggested that when SA concentration does not exceed $3.0 \times 10^{7} \mathrm{~cm}^{-3}$, the level of amines above $5 \mathrm{ppt}$ are sufficient to reach the rate limit for amine ternary nucleation. Although the median nighttime concentration of $\mathrm{C}_{2}$ amines (very likely DMA) was around 2.4 ppt (Fig. S9 and Table S5), there were also other base species (e.g., $\mathrm{C}_{3}$-amines, $\mathrm{NH}_{3}$ ) co-existing. Altogether, they are sufficient to stabilize SA clusters.

\section{Conclusions}

Continuous SA measurement was conducted during the heating-supply period in urban Beijing. Frequent nighttime SA events were found and accounted for about $32 \%$ of the total measurement nights. Most nighttime SA events were observed under unpolluted conditions and associated with a distinct drop in CS. We show that the SA source corresponding to the product of $\mathrm{O}_{3}$, alkenes and $\mathrm{SO}_{2}$ concentrations correlates well with the SA sink for clean conditions, and to some extent also for mildly polluted conditions. Therefore, we suggest that nighttime SA formation under these conditions can be largely attributed to the ozonolysis of alkenes, which leads to the production of $\mathrm{OH}$ radicals, as well as SCIs that are able to act as oxidants for $\mathrm{SO}_{2}$. However, further deconvolution of the contribution of $\mathrm{OH}$ radicals, SCIs and each possible alkene precursor was not possible within this study due to the inability to directly measure $\mathrm{OH}$, SCIs and the entire range of alkene precursors. It should also be pointed out that, under polluted conditions, there were very likely additional SA sources other than the ozonolysis of alkenes, such as direct emission from diesel vehicles, oil refineries and SA plants. Furthermore, we showed that during nighttime of winter Beijing, these elevated SA had a dominant contribution to the formation of sub- $3 \mathrm{~nm}$ particles, and the clustering mechanism at our site was more likely the SADMA- $\mathrm{H}_{2} \mathrm{O}$ nucleation.

Data availability. All the data for plotting figures in the main text as well as the Supplement are available and can be downloaded from https://doi.org/10.5281/zenodo.4572570 (Guo and Yan, 2021). For 
any further information, please contact the first author via email: sevenleaves1993@126.com.

Supplement. The supplement related to this article is available online at: https://doi.org/10.5194/acp-21-5499-2021-supplement.

Author contributions. CY, MK, LY, YL, LD and FB are acknowledged for valuable discussions. CL, ZF, YZ, ZL, RY and YW provided the relevant measurement data. And DS, RC, KRD, JeK, JuK and $\mathrm{BC}$ contributed to the article modification.

Competing interests. The authors declare that they have no conflict of interest.

Acknowledgements. Heikki Junninen is acknowledged for providing the tofTool package used for processing LTOF-CIMS data. Kaspar R. Daellenbach acknowledges the support from the SNF mobility grant P2EZP2_181599.

Financial support. This project has received funding from the National Natural Science Foundation of China (41877306), the ERC advanced grant no. 742206, the European Union's Horizon 2020 research and innovation program under grant agreement no. 654109, the Academy of Finland Center of Excellence Project no. 27204.

Open-access funding was provided by the Helsinki University Library.

Review statement. This paper was edited by Sally E. Pusede and reviewed by three anonymous referees.

\section{References}

Aalto, P., Hämeri, K., Becker, E., Weber, R., Salm, J., Mäkelä, J. M., Hoell, C., O'dowd, C. D., Hansson, H.-C., Väkevä, M., Koponen, I. K., Buzorius, G., and Kulmala, M.: Physical characterization of aerosol particles during nucleation events, Tellus B, 53, 344358, https://doi.org/10.3402/tellusb.v53i4.17127, 2001.

Ahn, J. Y., Okerlund, R., Fry, A., and Eddings, E. G.: Sulfur trioxide formation during oxy-coal combustion, Int. J. Greenh. Gas Con., 5, 127-135, https://doi.org/10.1016/j.ijggc.2011.05.009, 2011.

Almeida, J., Schobesberger, S., Kürten, A., Ortega, I. K., Kupiainen-Maatta, O., Praplan, A. P., Adamov, A., Amorim, A., Bianchi, F., Breitenlechner, M., David, A., Dommen, J., Donahue, N. M., Downard, A., Dunne, E., Duplissy, J., Ehrhart, S., Flagan, R. C., Franchin, A., Guida, R., Hakala, J., Hansel, A., Heinritzi, M., Henschel, H., Jokinen, T., Junninen, H., Kajos, M., Kangasluoma, J., Keskinen, H., Kupc, A., Kurten, T., Kvashin, A. N., Laaksonen, A., Lehtipalo, K., Leiminger, M., Leppa, J., Loukonen, V., Makhmutov, V., Mathot, S., McGrath, M. J.,
Nieminen, T., Olenius, T., Onnela, A., Petaja, T., Riccobono, F., Riipinen, I., Rissanen, M., Rondo, L., Ruuskanen, T., Santos, F. D., Sarnela, N., Schallhart, S., Schnitzhofer, R., Seinfeld, J. H., Simon, M., Sipila, M., Stozhkov, Y., Stratmann, F., Tome, A., Troestl, J., Tsagkogeorgas, G., Vaattovaara, P., Viisanen, Y., Virtanen, A., Vrtala, A., Wagner, P. E., Weingartner, E., Wex, H., Williamson, C., Wimmer, D., Ye, P., Yli-Juuti, T., Carslaw, K. S., Kulmala, M., Curtius, J., Baltensperger, U., Worsnop, D. R., Vehkamaki, H., and Kirkby, J.: Molecular understanding of sulphuric acid-amine particle nucleation in the atmosphere, Nature, 502, 359-363, https://doi.org/10.1038/nature12663, 2013.

Armendariz, A. J. and Leith, D.: Concentration measurement and counting efficiency for the aerodynamic particle sizer 3320 , J. Aerosol Sci., 33, 133-148, https://doi.org/10.1016/S00218502(01)00152-5, 2002.

Arnold, F., Pirjola, L., Aufmhoff, H., Schuck, T., Lahde, T., and Hameri, K.: First gaseous sulfuric acid measurements in automobile exhaust: Implications for volatile nanoparticle formation, Atmos. Environ., 40, 7097-7105, https://doi.org/10.1016/j.atmosenv.2006.06.038, 2006.

Aschmann, S. M.: OH Radical Production from the Gas-Phase Reaction of $\mathrm{O}_{3}$ with a Series of Alkenes under Atmospheric Conditions, Environ. Sci. Technol., 27, 1357-1363, 1993.

Aschmann, S. M., Tuazon, E. C., Arey, J., and Atkinson, R.: Products of the Gas-Phase Reaction of $\mathrm{O}_{3}$ with Cyclohexene, J. Phys Chem. A, 107, 2247-2255, https://doi.org/10.1021/jp022122e, 2003.

Atkinson, R., Aschmann, S. M., Arey, J., and Shorees, B.: Formation of $\mathrm{OH}$ radicals in the gas phase reactions of $\mathrm{O}_{3}$ with a series of terpenes, J. Geophys. Res.-Atmos., 97, 6065-6073, https://doi.org/10.1029/92JD00062, 1992.

Atkinson, R., Baulch, D. L., Cox, R. A., Crowley, J. N., Hampson, R. F., Hynes, R. G., Jenkin, M. E., Rossi, M. J., Troe, J., and IUPAC Subcommittee: Evaluated kinetic and photochemical data for atmospheric chemistry: Volume II - gas phase reactions of organic species, Atmos. Chem. Phys., 6, 3625-4055, https://doi.org/10.5194/acp-6-3625-2006, 2006.

Berndt, T., Böge, O., and Stratmann, F.: Gas-phase ozonolysis of $\alpha$-pinene: gaseous products and particle formation, Atmos. Environ., 37, 3933-3945, https://doi.org/10.1016/S13522310(03)00501-6, 2003.

Berndt, T., Jokinen, T., Sipila, M., Mauldin III, R. L., Herrmann, H., Stratmann, F., Junninen, H., and Kulmala, M.: $\mathrm{H}_{2} \mathrm{SO}_{4}$ formation from the gas-phase reaction of stabilized Criegee Intermediates with $\mathrm{SO}_{2}$ : Influence of water vapour content and temperature, Atmos. Environ., 89, 603-612, https://doi.org/10.1016/j.atmosenv.2014.02.062, 2014.

Birmili, W., Berresheim, H., Plass-Dülmer, C., Elste, T., Gilge, S., Wiedensohler, A., and Uhrner, U.: The Hohenpeissenberg aerosol formation experiment (HAFEX): a long-term study including size-resolved aerosol, $\mathrm{H}_{2} \mathrm{SO}_{4}, \mathrm{OH}$, and monoterpenes measurements, Atmos. Chem. Phys., 3, 361-376, https://doi.org/10.5194/acp-3-361-2003, 2003.

Boy, M., Karl, T., Turnipseed, A., Mauldin III, R. L., Kosciuch, E., Greenberg, J., Rathbone, J., Smith, J., Held, A., Barsanti, K., Wehner, B., Bauer, S., Wiedensohler, A., Bonn, B., Kulmala, M., and Guenther, A.: New particle formation in the Front Range of the Colorado Rocky Mountains, Atmos. Chem. Phys., 8, 15771590, https://doi.org/10.5194/acp-8-1577-2008, 2008. 
Cai, R., Yang, D., Fu, Y., Wang, X., Li, X., Ma, Y., Hao, J., Zheng, J., and Jiang, J.: Aerosol surface area concentration: a governing factor in new particle formation in Beijing, Atmos. Chem. Phys., 17, 12327-12340, https://doi.org/10.5194/acp-17-123272017, 2017.

Chew, A. A. and Atkinson, R.: $\mathrm{OH}$ radical formation yields from the gas-phase reactions of $\mathrm{O}_{3}$ with alkenes and monoterpenes, J. Geophys. Res.-Atmos., 101, 28649-28653, https://doi.org/10.1029/96JD02722, 1996.

Dada, L., Ylivinkka, I., Baalbaki, R., Li, C., Guo, Y., Yan, C., Yao, L., Sarnela, N., Jokinen, T., Daellenbach, K. R., Yin, R., Deng, C., Chu, B., Nieminen, T., Wang, Y., Lin, Z., Thakur, R. C., Kontkanen, J., Stolzenburg, D., Sipilä, M., Hussein, T., Paasonen, P., Bianchi, F., Salma, I., Weidinger, T., Pikridas, M., Sciare, J., Jiang, J., Liu, Y., Petäjä, T., Kerminen, V.-M., and Kulmala, M.: Sources and sinks driving sulfuric acid concentrations in contrasting environments: implications on proxy calculations, Atmos. Chem. Phys., 20, 11747-11766, https://doi.org/10.5194/acp-20-11747-2020, 2020.

Eerdekens, G., Yassaa, N., Sinha, V., Aalto, P. P., Aufmhoff, H., Arnold, F., Fiedler, V., Kulmala, M., and Williams, J.: VOC measurements within a boreal forest during spring 2005: on the occurrence of elevated monoterpene concentrations during night time intense particle concentration events, Atmos. Chem. Phys., 9, 8331-8350, https://doi.org/10.5194/acp-9-8331-2009, 2009.

Eisele, F. L., Lovejoy, E. R., Kosciuch, E., Moore, K. F., Mauldin III, R. L., Smith, J. N., McMurry, P. H., and Iida, K.: Negative atmospheric ions and their potential role in ioninduced nucleation, J. Geophys. Res.-Atmos., 111, D04305, https://doi.org/10.1029/2005jd006568, 2006.

Erupe, M. E., Benson, D. R., Li, J., Young, L.-H., Verheggen, B., Al-Refai, M., Tahboub, O., Cunningham, V., Frimpong, F., Viggiano, A. A., and Lee, S.-H.: Correlation of aerosol nucleation rate with sulfuric acid and ammonia in Kent, Ohio: An atmospheric observation, J. Geophys. Res.-Atmos., 115, D23216, https://doi.org/10.1029/2010jd013942, 2010

Fenske, J. D., Hasson, A. S., Ho, A. W., and Paulson, S. E.: Measurement of Absolute Unimolecular and Bimolecular Rate Constants for $\mathrm{CH}_{3} \mathrm{CHOO}$ Generated by the trans-2-Butene Reaction with Ozone in the Gas Phase, J. Phys. Chem. A, 104, 9921-9932, https://doi.org/10.1021/jp0016636, 2000.

Fiedler, V., Dal Maso, M., Boy, M., Aufmhoff, H., Hoffmann, J., Schuck, T., Birmili, W., Hanke, M., Uecker, J., Arnold, F., and Kulmala, M.: The contribution of sulphuric acid to atmospheric particle formation and growth: a comparison between boundary layers in Northern and Central Europe, Atmos. Chem. Phys., 5, 1773-1785, https://doi.org/10.5194/acp-5-1773-2005, 2005.

Gao, W., Tan, G., Hong, Y., Li, M., Nian, H., Guo, C., Huang, Z., Fu, Z., Dong, J., Xu, X., Cheng, P., and Zhou, Z.: Development of portable single photon ionization time-of-flight mass spectrometer combined with membrane inlet, Int. J. Mass Spectrom., 334, 8-12, https://doi.org/10.1016/j.ijms.2012.09.003, 2013.

Godunov, E. B., Kuznetsova, I. A., and Klevleev, V. M.: Comprehensive Utilization of Spent Sulfuric Acid from Petrochemical Industries and Chemical Current Sources, Chem. Petrol. Eng.+, 53, 531-533, https://doi.org/10.1007/s10556-017-0376-9, 2017.

Guo, Y. and Yan, C.: Dataset for acp-2019-1111: Formation of Nighttime Sulfuric Acid from the Ozonolysis of Alkenes in Beijing, Zenodo, https://doi.org/10.5281/zenodo.4572570, 2021.
Hasson, A. S., Orzechowska, G., and Paulson, S. E.: Production of stabilized Criegee intermediates and peroxides in the gas phase ozonolysis of alkenes 1. Ethene, trans-2-butene, and 2,3dimethyl-2-butene, J. Geophys. Res.-Atmos., 106, 34131-34142, https://doi.org/10.1029/2001jd000597, 2001.

Hatakeyama, S., Kobayashi, H., and Akimoto, H.: Gas-phase oxidation of sulfur dioxide in the ozone-olefin reactions, J. Phys. Chem., 88, 4736-4739, https://doi.org/10.1021/j150664a058, 1984.

Huang, H.-L., Chao, W., and Lin, J. J.-M.: Kinetics of a Criegee intermediate that would survive high humidity and may oxidize atmospheric $\mathrm{SO}_{2}$, P. Natl. Acad. Sci. USA, 112, 10857-10862, https://doi.org/10.1073/pnas.1513149112, 2015.

Iida, K., Stolzenburg, M. R., McMurry, P. H., and Smith, J. N.: Estimating nanoparticle growth rates from size-dependent charged fractions: Analysis of new particle formation events in Mexico City, J. Geophys. Res.-Atmos., 113, D05207, https://doi.org/10.1029/2007jd009260, 2008.

Jokinen, T., Sipilä, M., Junninen, H., Ehn, M., Lönn, G., Hakala, J., Petäjä, T., Mauldin III, R. L., Kulmala, M., and Worsnop, D. R.: Atmospheric sulphuric acid and neutral cluster measurements using CI-APi-TOF, Atmos. Chem. Phys., 12, 4117-4125, https://doi.org/10.5194/acp-12-4117-2012, 2012.

Jokinen, T., Sipila, M., Kontkanen, J., Vakkari, V., Tisler, P., Duplissy, E. M., Junninen, H., Kangasluoma, J., Manninen, H. E., Petaja, T., Kulmala, M., Worsnop, D. R., Kirkby, J., Virkkula, A., and Kerminen, V. M.: Ion-induced sulfuric acid-ammonia nucleation drives particle formation in coastal Antarctica, Science Advances, 4, eaat9744, https://doi.org/10.1126/sciadv.aat9744, 2018.

Junninen, H., Hulkkonen, M., Riipinen, I., Nieminen, T., Hirsikko, A., Suni, T., Boy, M., Lee, S.-H., Vana, M., Tammet, H., Kerminen, V.-M., and Kulmala, M.: Observations on nocturnal growth of atmospheric clusters, Tellus B, 60, 365-371, https://doi.org/10.1111/j.1600-0889.2008.00356.x, 2008.

Kammer, J., Perraudin, E., Flaud, P. M., Lamaud, E., Bonnefond, J. M., and Villenave, E.: Observation of nighttime new particle formation over the French Landes forest, Sci. Total Environ., 621, 1084-1092, https://doi.org/10.1016/j.scitotenv.2017.10.118, 2018.

Kecorius, S., Zhang, S., Wang, Z., Groess, J., Ma, N., Wu, Z., Ran, L., Hu, M., Wang, P., Ulevicius, V., and Wiedensohler, A.: Nocturnal Aerosol Particle Formation in the North China Plain, Lith. J. Phys., 55, 44-53, 2015.

Kirkby, J., Curtius, J., Almeida, J., Dunne, E., Duplissy, J., Ehrhart, S., Franchin, A., Gagne, S., Ickes, L., Kürten, A., Kupc, A., Metzger, A., Riccobono, F., Rondo, L., Schobesberger, S., Tsagkogeorgas, G., Wimmer, D., Amorim, A., Bianchi, F., Breitenlechner, M., David, A., Dommen, J., Downard, A., Ehn, M., Flagan, R. C., Haider, S., Hansel, A., Hauser, D., Jud, W., Junninen, H., Kreissl, F., Kvashin, A., Laaksonen, A., Lehtipalo, K., Lima, J., Lovejoy, E. R., Makhmutov, V., Mathot, S., Mikkila, J., Minginette, P., Mogo, S., Nieminen, T., Onnela, A., Pereira, P., Petaja, T., Schnitzhofer, R., Seinfeld, J. H., Sipila, M., Stozhkov, Y., Stratmann, F., Tome, A., Vanhanen, J., Viisanen, Y., Vrtala, A., Wagner, P. E., Walther, H., Weingartner, E., Wex, H., Winkler, P. M., Carslaw, K. S., Worsnop, D. R., Baltensperger, U., and Kulmala, M.: Role of sulphuric acid, ammonia and galac- 
tic cosmic rays in atmospheric aerosol nucleation, Nature, 476, 429-477, https://doi.org/10.1038/nature10343, 2011.

Kotzias, D., Fytianos, K., and Geiss, F.: Reaction of monoterpenes with ozone, sulphur dioxide and nitrogen dioxide - gasphase oxidation of $\mathrm{SO}_{2}$ and formation of sulphuric acid, Atmos. Environ. A-Gen., 24, 2127-2132, https://doi.org/10.1016/09601686(90)90246-J, 1990.

Kulmala, M., Maso, M. D., Mäkelä, J. M., Pirjola, L., Väkevä, M., Aalto, P., Miikkulainen, P., Hämeri, K., and O'dowd, C. D.: On the formation, growth and composition of nucleation mode particles, Tellus B, 53, 479-490, https://doi.org/10.3402/tellusb.v53i4.16622, 2001.

Kulmala, M., Lehtinen, K. E. J., and Laaksonen, A.: Cluster activation theory as an explanation of the linear dependence between formation rate of $3 \mathrm{~nm}$ particles and sulphuric acid concentration, Atmos. Chem. Phys., 6, 787-793, https://doi.org/10.5194/acp-6787-2006, 2006.

Kulmala, M., Kontkanen, J., Junninen, H., Lehtipalo, K., Manninen, H. E., Nieminen, T., Petäjä, T., Sipilä, M., Schobesberger, S., Rantala, P., Franchin, A., Jokinen, T., Järvinen, E., Äijälä, M., Kangasluoma, J., Hakala, J., Aalto, P. P., Paasonen, P., Mikkilä, J., Vanhanen, J., Aalto, J., Hakola, H., Makkonen, U., Ruuskanen, T., Mauldin III, R. L., Duplissy, J., Vehkamäki, H., Bäck, J., Kortelainen, A., Riipinen, I., Kurtén, T., Johnston, M. V., Smith, J. N., Ehn, M., Mentel, T. F., Lehtinen, K. E. J., Laaksonen, A., Kerminen, V.-M., and Worsnop, D. R.: Direct Observations of Atmospheric Aerosol Nucleation, Science, 339, $943-$ 946, https://doi.org/10.1126/science.1227385, 2013.

Kürten, A., Rondo, L., Ehrhart, S., and Curtius, J.: Calibration of a Chemical Ionization Mass Spectrometer for the Measurement of Gaseous Sulfuric Acid, J. Phys. Chem. A, 116, 6375-6386, https://doi.org/10.1021/jp212123n, 2012.

Kürten, A., Jokinen, T., Simon, M., Sipila, M., Sarnela, N., Junninen, H., Adamov, A., Almeida, J., Amorim, A., Bianchi, F., Breitenlechner, M., Dommen, J., Donahue, N. M., Duplissy, J., Ehrhart, S., Flagan, R. C., Franchin, A., Hakala, J., Hansel, A., Heinritzi, M., Hutterli, M., Kangasluoma, J., Kirkby, J., Laaksonen, A., Lehtipalo, K., Leiminger, M., Makhmutov, V., Mathot, S., Onnela, A., Petaja, T., Praplan, A. P., Riccobono, F., Rissanen, M. P., Rondo, L., Schobesberger, S., Seinfeld, J. H., Steiner, G., Tome, A., Troestl, J., Winkler, P. M., Williamson, C., Wimmer, D., Ye, P., Baltensperger, U., Carslaw, K. S., Kulmala, M., Worsnop, D. R., and Curtius, J.: Neutral molecular cluster formation of sulfuric acid-dimethylamine observed in real time under atmospheric conditions, P. Natl. Acad. Sci. USA, 111, 1501915024, https://doi.org/10.1073/pnas.1404853111, 2014.

Kürten, A., Bergen, A., Heinritzi, M., Leiminger, M., Lorenz, V., Piel, F., Simon, M., Sitals, R., Wagner, A. C., and Curtius, J.: Observation of new particle formation and measurement of sulfuric acid, ammonia, amines and highly oxidized organic molecules at a rural site in central Germany, Atmos. Chem. Phys., 16, $12793-$ 12813, https://doi.org/10.5194/acp-16-12793-2016, 2016.

Lee, S. H., Gordon, H., Yu, H., Lehtipalo, K., Haley, R., Li, Y. X., and Zhang, R. Y.: New Particle Formation in the Atmosphere: From Molecular Clusters to Global Climate, J. Geophys. Res.Atmos., 124, 7098-7146, https://doi.org/10.1029/2018jd029356, 2019.

Lehtipalo, K., Sipila, M., Junninen, H., Ehn, M., Berndt, T., Kajos, M. K., Worsnop, D. R., Petaja, T., and Kulmala, M.: Observations of Nano-CN in the Nocturnal Boreal Forest, Aerosol Sci. Tech., 45, 499-509, https://doi.org/10.1080/02786826.2010.547537, 2011.

Lehtipalo, K., Yan, C., Dada, L., Bianchi, F., Xiao, M., Wagner, R., Stolzenburg, D., Ahonen, L. R., Amorim, A., Baccarini, A., Bauer, P. S., Baumgartner, B., Bergen, A., Bernhammer, A.-K., Breitenlechner, M., Brilke, S., Buchholz, A., Mazon, S. B., Chen, D., Chen, X., Dias, A., Dommen, J., Draper, D. C., Duplissy, J., Ehn, M., Finkenzeller, H., Fischer, L., Frege, C., Fuchs, C., Garmash, O., Gordon, H., Hakala, J., He, X., Heikkinen, L., Heinritzi, M., Helm, J. C., Hofbauer, V., Hoyle, C. R., Jokinen, T., Kangasluoma, J., Kerminen, V.-M., Kim, C., Kirkby, J., Kontkanen, J., Kürten, A., Lawler, M. J., Mai, H., Mathot, S., Mauldin III, R. L., Molteni, U., Nichman, L., Nie, W., Nieminen, T., Ojdanic, A., Onnela, A., Passananti, M., Petaja, T., Piel, F., Pospisilova, V., Quelever, L. L. J., Rissanen, M. P., Rose, C., Sarnela, N., Schallhart, S., Schuchmann, S., Sengupta, K., Simon, M., Sipila, M., Tauber, C., Tome, A., Trostl, J., Vaisanen, O., Vogel, A. L., Volkamer, R., Wagner, A. C., Wang, M., Weitz, L., Wimmer, D., Ye, P., Ylisirnio, A., Zha, Q., Carslaw, K. S., Curtius, J., Donahue, N. M., Flagan, R. C., Hansel, A., Riipinen, I., Virtanen, A., Winkler, P. M., Baltensperger, U., Kulmala, M., and Worsnop, D. R.: Multicomponent new particle formation from sulfuric acid, ammonia, and biogenic vapors, Science Advances, 4, eaau5363, https://doi.org/10.1126/sciadv.aau5363, 2018.

Lu, Y., Yan, C., Fu, Y., Chen, Y., Liu, Y., Yang, G., Wang, Y., Bianchi, F., Chu, B., Zhou, Y., Yin, R., Baalbaki, R., Garmash, O., Deng, C., Wang, W., Liu, Y., Petäjä, T., Kerminen, V.-M., Jiang, J., Kulmala, M., and Wang, L.: A proxy for atmospheric daytime gaseous sulfuric acid concentration in urban Beijing, Atmos. Chem. Phys., 19, 1971-1983, https://doi.org/10.5194/acp19-1971-2019, 2019.

Malkin, T. L., Goddard, A., Heard, D. E., and Seakins, P. W.: Measurements of $\mathrm{OH}$ and $\mathrm{HO}_{2}$ yields from the gas phase ozonolysis of isoprene, Atmos. Chem. Phys., 10, 1441-1459, https://doi.org/10.5194/acp-10-1441-2010, 2010.

Mauldin III, R. L., Eisele, F. L., Tanner, D. J., Kosciuch, E., Shetter, R., Lefer, B., Hall, S. R., Nowak, J. B., Buhr, M., Chen, G., Wang, P., and Davis, D.: Measurements of $\mathrm{OH}, \mathrm{H}_{2} \mathrm{SO}_{4}$, and MSA at the South Pole during ISCAT, Geophys. Res. Lett., 28, 3629-3632, https://doi.org/10.1029/2000gl012711, 2001.

Mauldin III, R. L., Berndt, T., Sipilae, M., Paasonen, P., Petaja, T., Kim, S., Kurten, T., Stratmann, F., Kerminen, V. M., and Kulmala, M.: A new atmospherically relevant oxidant of sulphur dioxide, Nature, 488, 193-196, https://doi.org/10.1038/nature11278, 2012.

Mazon, S. B., Kontkanen, J., Manninen, H. E., Nieminen, T., Kerminen, V.-M., and Kulmala, M.: A long-term comparison of nighttime cluster events and daytime ion formation in a boreal forest, Boreal Environ. Res., 21, 242-261, 2016.

McMurry, P. H., Fink, M., Sakurai, H., Stolzenburg, M. R., Mauldin III, R. L., Smith, J., Eisele, F., Moore, K., Sjostedt, S., Tanner, D., Huey, L. G., Nowak, J. B., Edgerton, E., and Voisin, D.: A criterion for new particle formation in the sulfur-rich Atlanta atmosphere, J. Geophys. Res.-Atmos., 110, D22S02, https://doi.org/10.1029/2005jd005901, 2005.

Myllys, N., Chee, S., Olenius, T., Lawler, M., and Smith, J.: Molecular-Level Understanding of Synergistic Effects in Sul- 
furic Acid-Amine-Ammonia Mixed Clusters, J. Phys. Chem. A, 123, 2420-2425, https://doi.org/10.1021/acs.jpca.9b00909, 2019.

Neeb, P., Sauer, F., Horie, O., and Moortgat, G. K.: Formation of hydroxymethyl hydroperoxide and formic acid in alkene ozonolysis in the presence of water vapour, Atmos. Environ., 31, 14171423, https://doi.org/10.1016/S1352-2310(96)00322-6, 1997.

Newland, M. J., Rickard, A. R., Alam, M. S., Vereecken, L., Munoz, A., Rodenas, M., and Bloss, W. J.: Kinetics of stabilised Criegee intermediates derived from alkene ozonolysis: reactions with $\mathrm{SO}_{2}, \mathrm{H}_{2} \mathrm{O}$ and decomposition under boundary layer conditions, Phys. Chem. Chem. Phys., 17, 4076-4088, https://doi.org/10.1039/c4cp04186k, 2015a.

Newland, M. J., Rickard, A. R., Vereecken, L., Muñoz, A., Ródenas, M., and Bloss, W. J.: Atmospheric isoprene ozonolysis: impacts of stabilised Criegee intermediate reactions with $\mathrm{SO}_{2}$, $\mathrm{H}_{2} \mathrm{O}$ and dimethyl sulfide, Atmos. Chem. Phys., 15, 9521-9536, https://doi.org/10.5194/acp-15-9521-2015, 2015 b.

Nguyen, T. L., Peeters, J., and Vereecken, L.: Theoretical study of the gas-phase ozonolysis of $\beta$-pinene $\left(\mathrm{C}_{10} \mathrm{H}_{16}\right)$, Phys. Chem. Chem. Phys., 11, 5643-5656, https://doi.org/10.1039/b822984h, 2009.

Paasonen, P., Sihto, S.-L., Nieminen, T., Vuollekoski, H., Riipinen, I., Plass-Dulmer, C., Berresheim, H., Birmili, W., and Kulmala, M.: Connection between new particle formation and sulphuric acid at Hohenpeissenberg (Germany) including the influence of organic compounds, Boreal Environ. Res., 14, 616-629, 2009.

Paasonen, P., Nieminen, T., Asmi, E., Manninen, H. E., Petäjä, T., Plass-Dülmer, C., Flentje, H., Birmili, W., Wiedensohler, A., Hõrrak, U., Metzger, A., Hamed, A., Laaksonen, A., Facchini, M. C., Kerminen, V.-M., and Kulmala, M.: On the roles of sulphuric acid and low-volatility organic vapours in the initial steps of atmospheric new particle formation, Atmos. Chem. Phys., 10, 11223-11242, https://doi.org/10.5194/acp-10-112232010, 2010.

Riccobono, F., Schobesberger, S., Scott, C. E., Dommen, J., Ortega, I. K., Rondo, L., Almeida, J., Amorim, A., Bianchi, F., Breitenlechner, M., David, A., Downard, A., Dunne, E. M., Duplissy, J., Ehrhart, S., Flagan, R. C., Franchin, A., Hansel, A., Junninen, H., Kajos, M., Keskinen, H., Kupc, A., Kürten, A., Kvashin, A. N., Laaksonen, A., Lehtipalo, K., Makhmutov, V., Mathot, S., Nieminen, T., Onnela, A., Petaja, T., Praplan, A. P., Santos, F. D., Schallhart, S., Seinfeld, J. H., Sipila, M., Spracklen, D. V., Stozhkov, Y., Stratmann, F., Tome, A., Tsagkogeorgas, G., Vaattovaara, P., Viisanen, Y., Vrtala, A., Wagner, P. E., Weingartner, E., Wex, H., Wimmer, D., Carslaw, K. S., Curtius, J., Donahue, N. M., Kirkby, J., Kulmala, M., Worsnop, D. R., and Baltensperger, U.: Oxidation Products of Biogenic Emissions Contribute to Nucleation of Atmospheric Particles, Science, 344, 717-721, https://doi.org/10.1126/science.1243527, 2014.

Rickard, A. R., Johnson, D., McGill, C. D., and Marston, G.: $\mathrm{OH}$ Yields in the Gas-Phase Reactions of Ozone with Alkenes, J. Phys. Chem. A, 103, 7656-7664, https://doi.org/10.1021/jp9916992, 1999.

Riipinen, I., Sihto, S.-L., Kulmala, M., Arnold, F., Dal Maso, M., Birmili, W., Saarnio, K., Teinilä, K., Kerminen, V.-M., Laaksonen, A., and Lehtinen, K. E. J.: Connections between atmospheric sulphuric acid and new particle formation during QUEST III-IV campaigns in Heidelberg and Hyytiälä, Atmos. Chem.
Phys., 7, 1899-1914, https://doi.org/10.5194/acp-7-1899-2007, 2007.

Rose, C., Zha, Q., Dada, L., Yan, C., Lehtipalo, K., Junninen, H., Mazon, S. B., Jokinen, T., Sarnela, N., Sipila, M., Petaja, T., Kerminen, V.-M., Bianchi, F., and Kulmala, M.: Observations of biogenic ion-induced cluster formation in the atmosphere, Science Advances, 4, eaar5218, https://doi.org/10.1126/sciadv.aar5218, 2018.

Roy, B., Chen, L., and Bhattacharya, S.: Nitrogen Oxides, Sulfur Trioxide, and Mercury Emissions during Oxyfuel Fluidized Bed Combustion of Victorian Brown Coal, Environ. Sci. Technol., 48, 14844-14850, https://doi.org/10.1021/es504667r, 2014.

Salimi, F., Rahman, Md. M., Clifford, S., Ristovski, Z., and Morawska, L.: Nocturnal new particle formation events in urban environments, Atmos. Chem. Phys., 17, 521-530, https://doi.org/10.5194/acp-17-521-2017, 2017.

Sarnela, N., Jokinen, T., Nieminen, T., Lehtipalo, K., Junninen, H., Kangasluoma, J., Hakala, J., Taipale, R., Schobesberger, S., Sipila, M., Larnimaa, K., Westerholm, H., Heijari, J., Kerminen, V.M., Petaja, T., and Kulmala, M.: Sulphuric acid and aerosol particle production in the vicinity of an oil refinery, Atmos. Environ., 119, 156-166, https://doi.org/10.1016/j.atmosenv.2015.08.033, 2015.

Seinfeld, J. H. and Pandis, S. N.: Atmospheric chemistry and physics: from air pollution to climate change, 3rd Edn., John Wiley \& Sons, Inc., Hoboken, New Jersey, USA, 1152 pp., ISBN 978-1-118-94740-1, 2016.

Siese, M., Becker, K. H., Brockmann, K. J., Geiger, H., Hofzumahaus, A., Holland, F., Mihelcic, D., and Wirtz, K.: Direct Measurement of $\mathrm{OH}$ Radicals from Ozonolysis of Selected Alkenes: A EUPHORE Simulation Chamber Study, Environ. Sci. Technol., 35, 4660-4667, https://doi.org/10.1021/es010150p, 2001.

Sipilä, M., Jokinen, T., Berndt, T., Richters, S., Makkonen, R., Donahue, N. M., Mauldin III, R. L., Kurtén, T., Paasonen, P., Sarnela, N., Ehn, M., Junninen, H., Rissanen, M. P., Thornton, J., Stratmann, F., Herrmann, H., Worsnop, D. R., Kulmala, M., Kerminen, V.-M., and Petäjä, T.: Reactivity of stabilized Criegee intermediates (sCIs) from isoprene and monoterpene ozonolysis toward $\mathrm{SO}_{2}$ and organic acids, Atmos. Chem. Phys., 14, 12143 12153, https://doi.org/10.5194/acp-14-12143-2014, 2014.

Srivastava, R. K., Miller, C. A., Erickson, C., and Jambhekar, R.: Emissions of sulfur trioxide from coal-fired power plants, J. Air Waste Manage., 54, 750-762, https://doi.org/10.1080/10473289.2004.10470943, 2004.

Stocker, T. F., Qin, D., Plattner, G.-K., Tignor, M. M., Allen, S. K., Boschung, J., Nauels, A., Xia, Y., Bex, V., and Midgley, P. M.: Climate Change 2013: The physical science basis, in: Contribution of working group I to the fifth assessment report of The Intergovernmental Panel on Climate Change (IPCC), Cambridge University Press, Cambridge, UK, 121 pp., 2014.

Taatjes, C. A., Welz, O., Eskola, A. J., Savee, J. D., Scheer, A. M., Shallcross, D. E., Rotavera, B., Lee, E. P. F., Dyke, J. M., Mok, D. K. W., Osborn, D. L., and Percival, C. J.: Direct Measurements of Conformer-Dependent Reactivity of the Criegee Intermediate $\mathrm{CH}_{3} \mathrm{CHOO}$, Science, 340, 177-180, https://doi.org/10.1126/science.1234689, 2013.

Taipale, R., Sarnela, N., Rissanen, M., Junninen, H., Rantala, P., Korhonen, F., Siivola, E., Berndt, T., Kulmala, M., Mauldin III, R. L., Petaja, T., and Sipila, M.: New instrument for measuring 
atmospheric concentrations of non-OH oxidants of $\mathrm{SO}_{2}$, Boreal Environ. Res., 19, 55-70, 2014.

Vanhanen, J., Mikkila, J., Lehtipalo, K., Sipila, M., Manninen, H. E., Siivola, E., Petaja, T., and Kulmala, M.: Particle Size Magnifier for Nano-CN Detection, Aerosol Sci. Tech., 45, 533-542, https://doi.org/10.1080/02786826.2010.547889, 2011.

Vereecken, L., Novelli, A., and Taraborrelli, D.: Unimolecular decay strongly limits the atmospheric impact of Criegee intermediates, Phys. Chem. Chem. Phys., 19, 31599-31612, https://doi.org/10.1039/c7cp05541b, 2017.

Wang, Z. B., Hu, M., Yue, D. L., Zheng, J., Zhang, R. Y., Wiedensohler, A., Wu, Z. J., Nieminen, T., and Boy, M.: Evaluation on the role of sulfuric acid in the mechanisms of new particle formation for Beijing case, Atmos. Chem. Phys., 11, 12663-12671, https://doi.org/10.5194/acp-11-12663-2011, 2011.

Weber, R. J., Marti, J. J., McMurry, P. H., Eisele, F. L., Tanner, D. J., and Jefferson, A.: Measurements of new particle formation and ultrafine particle growth rates at a clean continental site, J. Geophys. Res.-Atmos., 102, 4375-4385, https://doi.org/10.1029/96jd03656, 1997.

Weber, R. J., McMurry, P. H., Mauldin, L., Tanner, D. J., Eisele, F. L., Brechtel, F. J., Kreidenweis, S. M., Kok, G. L., Schillawski, R. D., and Baumgardner, D.: A study of new particle formation and growth involving biogenic and trace gas species measured during ACE 1, J. Geophys. Res.-Atmos., 103, 16385-16396, https://doi.org/10.1029/97jd02465, 1998.

Weber, R. J., McMurry, P. H., Mauldin III, R. L., Tanner, D. J., Eisele, F. L., Clarke, A. D., and Kapustin, V. N.: New Particle Formation in the Remote Troposphere: A Comparison of Observations at Various Sites, Geophys. Res. Lett., 26, 307-310, https://doi.org/10.1029/1998g1900308, 1999.

Welz, O., Savee, J. D., Osborn, D. L., Vasu, S. S., Percival, C. J., Shallcross, D. E., and Taatjes, C. A.: Direct Kinetic Measurements of Criegee Intermediate $\left(\mathrm{CH}_{2} \mathrm{OO}\right)$ Formed by Reaction of $\mathrm{CH}_{2} \mathrm{I}$ with $\mathrm{O}_{2}$, Science, 335, 204-207, https://doi.org/10.1126/science.1213229, 2012.

Welz, O., Eskola, A. J., Sheps, L., Rotavera, B., Savee, J. D., Scheer, A. M., Osborn, D. L., Lowe, D., Booth, A. M., Xiao, P., Khan, M. A. H., Percival, C. J., Shallcross, D. E., and Taatjes, C. A.: Rate Coefficients of $\mathrm{C} 1$ and $\mathrm{C} 2$ Criegee Intermediate Reactions with Formic and Acetic Acid Near the Collision Limit: Direct Kinetics Measurements and Atmospheric Implications, Angew. Chem. Int. Edit., 53, 4547-4550, https://doi.org/10.1002/anie.201400964, 2014.
Witter, M., Berndt, T., Böge, O., Stratmann, F., and Heintzenberg, J.: Gas-phase ozonolysis: Rate coefficients for a series of terpenes and rate coefficients and $\mathrm{OH}$ yields for 2-methyl-2-butene and 2,3-dimethyl-2-butene, Int. J. Chem. Kinet., 34, 394-403, https://doi.org/10.1002/kin.10063, 2002.

Yao, L., Garmash, O., Bianchi, F., Zheng, J., Yan, C., Kontkanen, J., Junninen, H., Mazon, S. B., Ehn, M., Paasonen, P., Sipila, M., Wang, M. Y., Wang, X. K., Xiao, S., Chen, H. F., Lu, Y. Q., Zhang, B. W., Wang, D. F., Fu, Q. Y., Geng, F. H., Li, L., Wang, H. L., Qiao, L. P., Yang, X., Chen, J. M., Kerminen, V. M., Petaja, T., Worsnop, D. R., Kulmala, M., and Wang, L.: Atmospheric new particle formation from sulfuric acid and amines in a Chinese megacity, Science, 361, 278-281, https://doi.org/10.1126/science.aao4839, 2018.

Yao, L., Fan, X., Yan, C., Kurten, T., Daellenbach, K. R., Li, C., Wang, Y., Guo, Y., Dada, L., Rissanen, M. P., Cai, J., Tham, Y. J., Zha, Q., Zhang, S., Du, W., Yu, M., Zheng, F., Zhou, Y., Kontkanen, J., Chan, T., Shen, J., Kujansuu, J. T., Kangasluoma, J., Jiang, J., Wang, L., Worsnop, D. R., Petaja, T., Kerminen, V. M., Liu, Y., Chu, B., He, H., Kulmala, M., and Bianchi, F.: Unprecedented Ambient Sulfur Trioxide $\left(\mathrm{SO}_{3}\right)$ Detection: Possible Formation Mechanism and Atmospheric Implications, Environ. Sci. Tech. Let., 7, 809-818, https://doi.org/10.1021/acs.estlett.0c00615, 2020.

Yu, H., McGraw, R., and Lee, S.-H.: Effects of amines on formation of sub-3 nm particles and their subsequent growth, Geophys. Res. Lett., 39, L02807, https://doi.org/10.1029/2011g1050099, 2012.

Yu, H., Hallar, A. G., You, Y., Sedlacek, A., Springston, S., Kanawade, V. P., Lee, Y. N., Wang, J., Kuang, C. G., McGraw, R. L., McCubbin, I., Mikkila, J., and Lee, S. H.: Sub$3 \mathrm{~nm}$ particles observed at the coastal and continental sites in the United States, J. Geophys. Res.-Atmos., 119, 860-879, https://doi.org/10.1002/2013jd020841, 2014.

Zhang, D. and Zhang, R.: Ozonolysis of alpha-pinene and betapinene: Kinetics and mechanism, J. Chem. Phys., 122, 114308 , https://doi.org/10.1063/1.1862616, 2005.

Zhang, D., Lei, W. F., and Zhang, R. Y.: Mechanism of OH formation from ozonolysis of isoprene: kinetics and product yields, Chem. Phys. Lett., 358, 171-179, https://doi.org/10.1016/s00092614(02)00260-9, 2002. 